\title{
LC-MS Analysis, 15-Lipoxygenase Inhibition, Cytotoxicity, and Genotoxicity of Dissotis multiflora (Sm) Triana (Melastomataceae) and Paullinia pinnata Linn (Sapindaceae)
}

\author{
Alian Désiré Afagnigni $\left(\mathbb{D},{ }^{1}\right.$ Maximilienne Ascension Nyegue $\mathbb{D}^{\mathrm{D}},{ }^{2}$ Steve Valdi Djova $\mathbb{D}^{\mathrm{D}}{ }^{1}$ \\ and François-Xavier Etoa ${ }^{2}$ \\ ${ }^{1}$ Department of Biochemistry, Faculty of Science, University of Yaounde I, P.O. Box: 812, Yaounde, Cameroon \\ ${ }^{2}$ Department of Microbiology, Faculty of Science, University of Yaounde I, P.O. Box: 812, Yaounde, Cameroon \\ Correspondence should be addressed to Alian Désiré Afagnigni; afagnigni2007@yahoo.fr
}

Received 30 September 2019; Revised 15 January 2020; Accepted 25 January 2020; Published 18 February 2020

Academic Editor: Jean-Paul J. Gonzalez

Copyright ( 2020 Alian Désiré Afagnigni et al. This is an open access article distributed under the Creative Commons Attribution License, which permits unrestricted use, distribution, and reproduction in any medium, provided the original work is properly cited.

\begin{abstract}
This study aims to evaluate the anti-inflammatory, cytotoxicity, and genotoxicity activities of Dissotis multiflora (Sm) Triana and Paullinia pinnata Linn used traditionally in Cameroon to treat infectious diseases. Phytochemical screening was carried out using the LC-MS procedure. The ferrous oxidation-xylenol orange (FOX) assay was used to determine the 15-lipoxygenase (15-LOX) inhibitory activity of the plant samples. The tetrazolium-based colorimetric (MTT) assay was performed using Vero cells. The Ames test was carried out using Salmonella typhimurium TA98 and TA100 tester strains. LC-MS chromatogram of D. multiflora led to the identification of four known compounds, namely, 5-(3,5-dinitrophenyl)-2H-tetrazol (2), 2,2'-\{[2-(6-amino-9H-purine9-yl)ethyl]imino\}diethanol (14), 1,2,5-oxadiazolo [3,4-b]pyrazine, 5,6-di (3,5-dimethyl-1-piperidyl) (19), and nimbolinin D (20) while four compounds were also identified in P. pinnata known as 2-hydroxycarbamoyl-4-methyl-pentanoic acid (2), pheophorbide A (16), 1-[4-(\{2-[(1-methyl-1H-indol-5-yl)amino]-4-pyrimidinyl $\}$ oxy)-1-naphthyl]-3-[1-(4 methylphenyl)-3-(2methyl-2-propanyl)-1H-pyrazol-5-yl]urea (17), and nimbolinin D (18). D. multiflora and P. pinnata inhibited 15-LOX activity in concentration-dependent manner. The $\mathrm{LC}_{50}$ (concentration that kills $50 \%$ of cells) values of the extracts ranged from $0.13 \pm 00$ to $1 \pm 00 \mathrm{mg} / \mathrm{mL}$ for $P$. pinnata and D. multiflora, respectively. $P$. pinnata was cytotoxic at concentrations tested while $D$. multiflora was not. The selectivity index (SI) values ranged from 0.16 to 10.30 on Vero cell lines. No genotoxic effect was observed against both strains tested. These extracts are sources of compounds which can be used to control infectious diseases and associated inflammation. However, caution should be taken while using P. pinnata for medicinal purposes.
\end{abstract}

\section{Background}

Inflammation is the immune system's reaction to infection and injury involved in the pathogeneses of arthritis, cancer, stroke, neurodegenerative, and cardiovascular disease. This even removes offending factors and restores tissue structure and physiological function [1]. However, a massive production of proinflammatory molecules such as interleukin-6 (IL-6), tumour necrosis factor- $\alpha$ (TNF- $\alpha$ ), and nitric oxide (NO) can modulate inflammation $[2,3]$.

Several studies have shown evidence of plant biological activities [4]. Since ancient times, plants are used for treatment of various diseases and are often assumed to be safe [5]. However, the lack of data on the toxicity of plants necessitates exhaustive evaluation of their safety given that some of them are a primary source of cytotoxic and genotoxic substances which can induce adverse effects [6-8]. Therefore, it is important to evaluate the efficacy and toxicity of natural products prior to potential use as antimicrobial agents [9].

In the search for effective safe natural antibacterial and anti-inflammatory compounds, the current study selected two Cameroonian medicinal plants based on their traditional use. Aqueous decoctions and powdered leaves from 
Dissotis multiflora (Sm) Triana from the Melastomataceae family are widely used in the Cameroon traditional medicine to treat infectious diseases and related conditions including diarrhea. In terms of biological activities, few studies have reported the presence of phytochemicals, antibacterial, antioxidant, and antidiarrheal activities of ethanolic leaf extract of D. multiflora $[10,11]$. Paullinia pinnata Linn from the Sapindaceae family is used for the treatment of wounds and other skin diseases, typhoid, syphilis, gonorrhea, stomachache, waist pain, and diarrhea [12]. Modern pharmacology research has indicated that the different parts of $P$. pinnata possesses antioxidant, antidiarrheal, antityphoid, antibacterial, wound healing, cytoprotective, anti-inflammatory, and anxiolytic activities [13-19]. Phytochemical studies of $P$. pinnata revealed the presence of secondary metabolites while numerous phenolic compounds with biological activities have been isolated [20-24].

The widespread use of $D$. multiflora and $P$. pinnata for medicinal purposes to treat several infectious diseases motivated this study, knowing that there are no or few previous studies reporting their anti-inflammatory activity, cytotoxicity, and genotoxicity. Therefore, the present work was designed to investigate the 15-LOX inhibitory activity, cytotoxicity, and genotoxicity of $D$. multiflora and P. pinnata ethanolic extracts.

\section{Materials and Methods}

2.1. Plant Material and Extraction. The leaves of Dissotis multiflora (Sm) Triana (Melastomataceae) and Paullinia pinnata Linn (Sapindaceae) were collected in December 2013 in Nkoupa Matapit, West Cameroon. Plant identification and extraction were done as previously described $[11,19]$.

2.2. Cell Culture. African green monkey (Vero) kidney cell lines obtained from the American Type Culture Collection (ATCC) were maintained at $37^{\circ} \mathrm{C}$ and $5 \% \mathrm{CO}_{2}$ in a humidified environment in modified Eagle's medium (MEM) high glucose $(4.5 \mathrm{~g} / \mathrm{L})$ containing L-glutamine (Lonza, Belgium) and supplemented with $5 \%$ foetal bovine serum (Capricorn Scientific GmbH, South America) and 1\% gentamicin (Virbac, RSA).

2.3. LC-MS Procedure. LC-MS analysis of D. multiflora and $P$. pinnata extracts was carried out following a modified method of Abay et al. [25] as previously described by Gheorghe et al. [26]. An oven with reverse phase column $\mathrm{C}_{18}$ $\left(30^{\circ} \mathrm{C}\right)$ was used.

2.4. Inhibition of 15-Lipoxygenase (15-LOX) Enzyme. The assay was performed spectrophotometrically based on the formation of the complex $\mathrm{Fe}^{3+} /$ xylenol orange according to Pinto et al. [27] as previously described by Motlhatlego et al. [28].
2.5. Cytotoxicity Assay. Cytotoxicity of the extract was determined in the MTT [3-(4, 5-dimethylthiazol-2-yl)-2, 5 diphenyltetrazolium bromide] reduction assay against Vero cell lines according to Mosmann [29] as described by Omokhua et al. [30]. From the previously reported MIC values $[10,19]$ and lethal concentration $50\left(\mathrm{LC}_{50}\right)$ values obtained in the current study, the selectivity index (SI) values were calculated using the following formula: $\mathrm{SI}=\mathrm{LC}_{50} / \mathrm{MIC}$.

2.6. Genototoxicity Assay. The genotoxicity evaluation of plant samples was done in the histidine-deficient growth medium using the Salmonella microsome assay according to Maron and Ames [31] as described by Omokhua et al. [30].

2.7. Statistical Analysis. Each experiment was performed in triplicates. Data are expressed as mean \pm standard deviation. Microsoft Excel was used to enter and capture data from which graphs and tables were extracted.

\section{Results and Discussion}

3.1. LC-MS Analysis of Plant Extracts. LC-MS of D. multiflora and $P$. pinnata revealed the presence of many compounds with known or unknown therapeutic potentials. The LC-MS chromatogram of D. multiflora (Figure 1(a)) showed 36 peaks from which four compounds were identified (Figure 1(b)), namely, the 5-(3,5dinitrophenyl)-2H-tetrazole (2), pseudo-molecular ion peak at $\mathrm{m} / \mathrm{z} 290 \mathrm{~g} / \mathrm{mol}[\mathrm{M}+\mathrm{H}]+$ corresponding to the molecular formula $\mathrm{C}_{7} \mathrm{H}_{4} \mathrm{~N}_{6} \mathrm{O}_{4}$ and retention time of $0.4 \mathrm{~min}, 2,2^{\prime}-\{[2-(6$-amino-9H-purine-9-yl)ethyl $]$ imino $\}$ diethanol (14) molecular formula $\mathrm{C}_{15} \mathrm{H}_{18} \mathrm{~N}_{6} \mathrm{O}_{2}$, molecular weight $314.34 \mathrm{~g} / \mathrm{mol}$, and retention time of $4.4 \mathrm{~min}, 1,2,5-$ oxadiazolo [3,4-b]pyrazine, 5,6-di(3,5-dimethyl-1-piperidyl) (19), pseudo-molecular ion peak at $\mathrm{m} / \mathrm{z} 345.2397[\mathrm{M}+\mathrm{H}]+$ corresponding to the molecular formula $\mathrm{C}_{17} \mathrm{H}_{27} \mathrm{~N}_{6} \mathrm{O}$ and retention time of $5.2 \mathrm{~min}$, and nimbolinin $\mathrm{D}$ (20), molecular formula $\mathrm{C}_{36} \mathrm{H}_{44} \mathrm{O}_{9}$, molecular ion peak at m/z $621.3083 \mathrm{~g} / \mathrm{mol}$ $[\mathrm{M}+\mathrm{H}]+$, and retention time of $5.7 \mathrm{~min}$. 5-(3,5-dinitrophenyl)-2H-tetrazole derivatives were found to possess antimycobacterial, antibacterial, antifungal, and cytotoxic properties [32] while nimbolinin D possess anti-inflammatory activity, especially the inhibition of the production of nitric oxide [33]. The presence of bioactive constituents in the ethanolic leaf of $D$. multiflora gives scientific basis for the use of this plant which is underexploited and here screened for the first time for its chromatographic profile.

Concerning $P$. pinnata, the LC-MS chromatogram (Figure 2(a)) showed 28 peaks from which four compounds were identified (Figure 2(b)), namely, the 2-hydroxycarbamoyl-4-methyl-pentanoic acid (2), molecular formula $\mathrm{C}_{7} \mathrm{H}_{13} \mathrm{NO}_{4}$, molecular weight $184 \mathrm{~g} / \mathrm{mol}$, and retention time of $0.4 \mathrm{~min}$, pheophorbide A (16), molecular formula $\mathrm{C}_{35} \mathrm{H}_{36} \mathrm{~N}_{4} \mathrm{O}_{5}$, molecular ion peak at $\mathrm{m} / \mathrm{z} 593.2763 \mathrm{~g} / \mathrm{mol}$ $[\mathrm{M}+\mathrm{H}]+$, and retention time of $5.4 \mathrm{~min}, 1-[4-(\{2-[(1-$ methyl-1H-indol-5-yl)amino]-4 -pyrimidinyl $\} o x y)$-1-naphthyl]-3-[1-(4 methylphenyl)-3-(2-methyl-2-propanyl)-1H- 


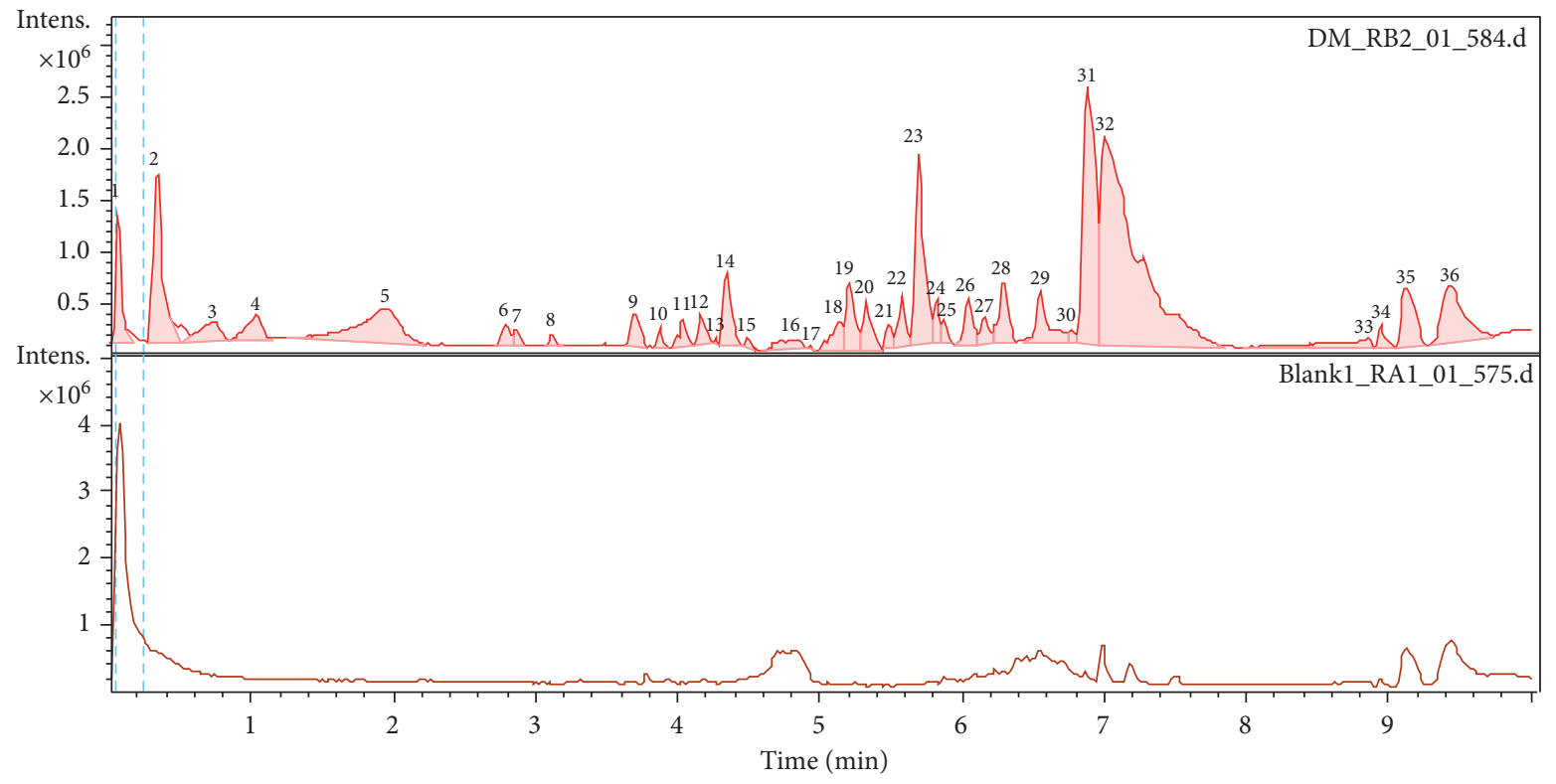

(a)<smiles>O=[N+]([O-])c1cc(-c2nn[nH]n2)cc([N+](=O)[O-])c1</smiles>

2<smiles>Nc1ncnc2c1ncn2-c1ccc(N(CCO)CCO)cc1</smiles>

14<smiles>CC1CC(C)CN(c2nc3nonc3nc2N2CC(C)CC(C)C2)C1</smiles><smiles>CO[C@H]1CC2[C@@]3(C)C4C(OC[C@]4(C)[C@@H](OC(C)=O)C[C@H]3O)[C@@H](OC(=O)c3ccccc3)[C@@]2(C)C2=C(C)[C@@H](c3ccoc3)CC2O1</smiles>

(b)

Figure 1: (a) LC-MS spectrum of D. multiflora leaf extract. (b) Chemical structures of 4 compounds identified in the leaf extract of D. multiflora. 


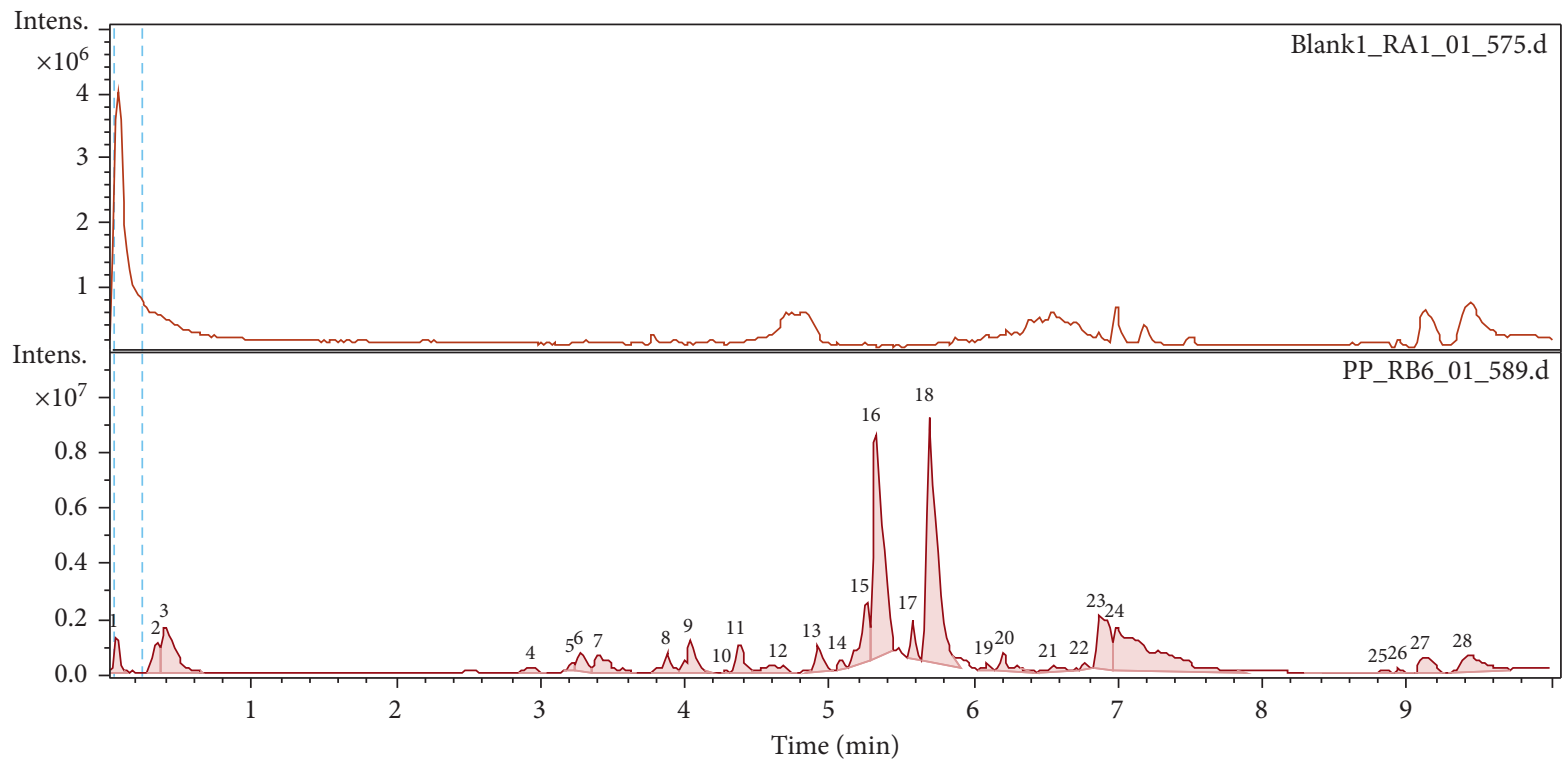

(a)<smiles>CC(C)CC(C(=O)O)C(=O)NO</smiles>

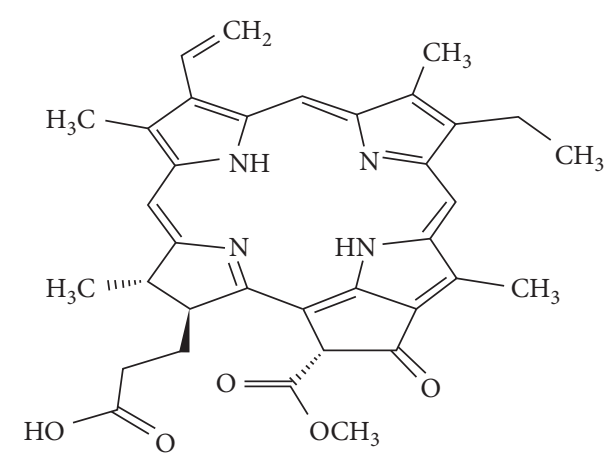<smiles>Cc1ccc(N2CN=C(C(C)(C)C)C=C2NC(N)=O)cc1</smiles><smiles>Cn1ccc2cc(Nc3nccc(Oc4ccc(N)c5ccccc45)n3)ccc21</smiles>
17

(b)

Figure 2: (a) LC-MS spectrum of P. pinnata leaf extract. (b) Chemical structures of 4 compounds identified in the leaf extract of $P$. pinnata.

pyrazol-5-yl]urea (17), molecular formula $\mathrm{C}_{37} \mathrm{H}_{36} \mathrm{~N}_{8} \mathrm{O}_{2}$, molecular weight $637.3042 \mathrm{~g} / \mathrm{mol}$, and retention time of $5.6 \mathrm{~min}$, and nimbolinin (18) D, molecular formula $\mathrm{C}_{36} \mathrm{H}_{44} \mathrm{O}_{9}$, molecular ion peak at $\mathrm{m} / \mathrm{z} 621.3083 \mathrm{~g} / \mathrm{mol}$ $[\mathrm{M}+\mathrm{H}]+$, and retention time of $5.7 \mathrm{~min}$. Amongst the fourth identified compounds, nimbolinin and pheophorbide A are known compounds present in other plants used also in traditional medicine. Nimbolinin D exhibited anti-inflammatory activity [33] while pheophorbide A was cytostatic, induced interruption of G0/G1 phasis and U87 MG cells apoptosis in the absence of direct photoactivation [34]. It also induced significant antiproliferative effects in a 


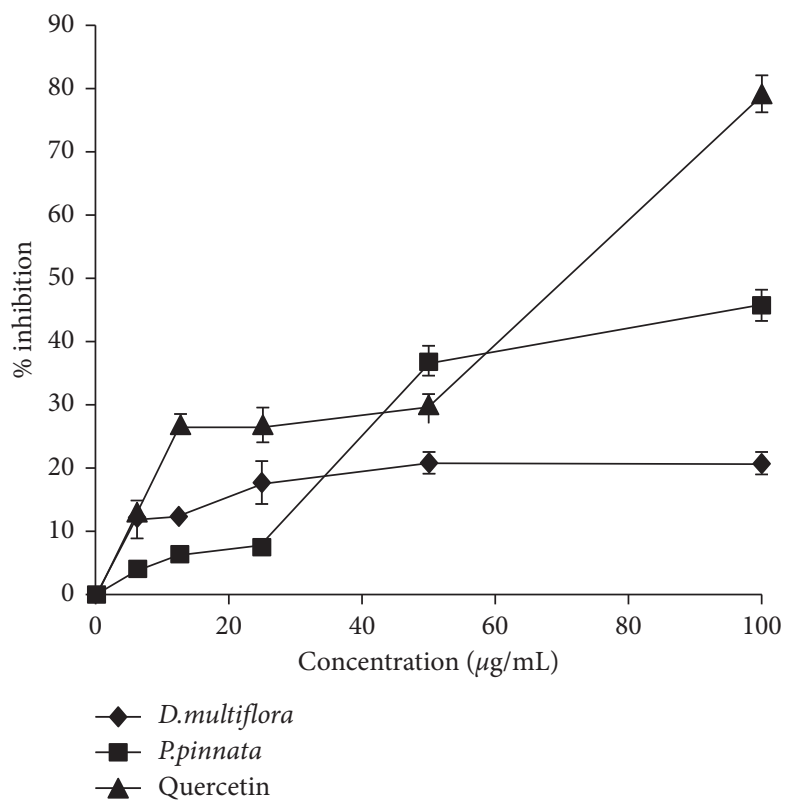

Figure 3: Inhibitory activity of the ethanolic extracts and fractions from D. multiflora and P. pinnata on 15-lipoxygenase. Data are expressed as mean \pm standard deviation of three replicates.

number of human cancer cell lines [35]. The identification of new constituents in $P$. pinnata leaf extract adds to the existing data that emphasize the presence of numerous bioactive compounds isolated and characterized [20-22, 24].

3.2. Inhibition of 15-Lipoxygenase (15-LOX) Enzyme. The 15LOX enzyme intervenes in the synthesis of leukotrienes from arachidonic acid. It has been proven that the bioactive leukotrienes are mediators of numerous proinflammatory and allergic reactions. Therefore, the 15-LOX inhibition activity is the most important one, even in the control of inflammatory conditions [36]. The 15-LOX inhibitory activity of ethanolic extracts from $D$. multiflora and $P$. pinnata was evaluated at different concentrations $(6.25,12.5,25,50$, and $100 \mu \mathrm{g} / \mathrm{mL})$ and compared with quercetin (Figure 3). Extracts exhibited 15-LOX inhibitory effects in a concentration-dependant manner with inhibition percentage varying between 4 and $45.85 \%$ for the extracts of both plants. Phenol was found in both extracts and may be responsible of the 15-LOX inhibitory activity $[10,37]$.

3.3. Cytotoxicity Assay. The cytotoxicity test was performed against Vero monkey kidney cells to ensure the safe use of $D$. multiflora and $P$. pinnata. The $\mathrm{LC}_{50}$ values of the extracts ranged between $0.13 \pm 00$ and $1 \pm 00 \mathrm{mg} / \mathrm{mL}$ for crude extracts from $P$. pinnata and $D$. multiflora, respectively (Table 1). It has been shown that $\mathrm{LC}_{50}$ values of $20 \mu \mathrm{g} / \mathrm{mL}$ and below were considered to be toxic [38]. In this sense, all extracts are nontoxic. In a previous study, we determined the antibacterial activity of the ethanolic leaf extracts of $D$. multiflora and P. pinnata against Salmonella typhi, Shigella flexneri, Proteus mirabilis, Klebsiella pneumoniae, Bacillus cereus, and Escherichia coli $[10,19]$. The SI values of the extracts were calculated by dividing the cytotoxicity $\mathrm{LC}_{50}$ (in $\mathrm{mg} / \mathrm{mL}$ ) by MIC $(\mathrm{mg} / \mathrm{mL})$. Results showed that the SI values ranged between 1.28 and 10.30 for $D$. multiflora while varying from 0.16 to 0.66 for P. pinnata (Table 1). According to Mongalo et al. [39], SI values above 1 refer to less toxic and below 1 to be toxic. Hence, D. multiflora with SI values above 1 showed no preliminary indication of toxicity while $P$. pinnata with SI values lower than 1 may be devoid of antibacterial activity. To the best of our knowledge, the present study reports for the first time the cytotoxicity of D. multiflora. In an in vivo study, D. multiflora was reported to be devoid of subacute toxicity at doses lower than $200 \mathrm{mg} / \mathrm{kg}$. The cytotoxic potential of the crude plant extract of Dissotis rotundifolia, a plant of the same genera, was reported to be highly toxic to the MRC-5 cell line [40] while Abere et al. [41] reported that doses lower than $500 \mathrm{mg} / \mathrm{kg}$ were nontoxic by subacute toxicity. $P$. pinnata ethanolic leaf extracts were less active against the bacterial strains. Hence, the worse selectivity indices at concentrations tested. The in vivo toxicity test has shown that $P$. pinnata extract was not toxic at doses up to $200 \mathrm{mg} / \mathrm{kg}$ $[24,42]$. One should observe that the results of in vitro toxicity evaluation differ substantially from that observed in vivo. This may be due to pharmacokinetic and pharmacodynamical considerations [43].

3.4. Genotoxicity Assay. The genotoxicity test was performed in order to determine ranges of plant extracts capable of producing genetic damage with resultant gene mutations without metabolic activation. From the Ames test, we observed that all the extracts tested at various concentrations had no number of revertant colonies of $S$. typhimurium strains TA98 and TA100 equal to or greater than twice those of the negative control (Table 2). Therefore, both plant extracts did not induce 
TABLe 1: Cytotoxic effects and selectivity index values of ethanolic leaf extract of D. multiflora and P. pinnata on Vero cells.

\begin{tabular}{|c|c|c|c|c|c|c|c|}
\hline \multirow{2}{*}{ Plant } & \multirow{2}{*}{$\mathrm{LC}_{50}(\mathrm{mg} / \mathrm{mL})$} & \multicolumn{6}{|c|}{ Selectivity index (SI) } \\
\hline & & S. typhi & S. flex & K. pneu & B. cer & E. coli & P. mirab \\
\hline D. multiflora & $1.00 \pm 0.00$ & 10.30 & 5.12 & 5.12 & 1.28 & 2.56 & 2.56 \\
\hline P. pinnata & $0.13 \pm 0.06$ & 0.16 & 0.66 & 0.33 & 0.16 & 0.16 & 0.33 \\
\hline Doxorubicin & $5.92 \pm 1.21$ & - & - & - & - & - & - \\
\hline
\end{tabular}

S. typhi: Salmonella typhi; S. flex: Shigella flexneri; K. pneu: K. pneumoniae; B. cer: Bacillus cereus; E. coli: Escherichia coli; P. mirab: Proteus mirabilis. Doxorubicin hydrochloride in $\mu \mathrm{g} / \mathrm{mL}$ was used as positive control. Minimum inhibitory concentration values of extracts (mg/mL) from previous works; $\mathrm{LC}_{50}=$ Lowest concentration of extract which is lethal to $50 \%$ of the cells.

TABLe 2: Number of revertant colonies of Salmonella typhimurium TA98 and TA100 tester strains induced by ethanolic extracts of D. multiflora and P. pinnata.

\begin{tabular}{|c|c|c|c|}
\hline \multirow{2}{*}{ Plant } & \multirow{2}{*}{ Concentration $(\mathrm{mg} / \mathrm{mL})$} & \multicolumn{2}{|c|}{ His + revertants plate } \\
\hline & & TA98 & TA100 \\
\hline \multirow{3}{*}{ D. multiflora } & 5 & $23.00 \pm 0.57(1.131)$ & $135.00 \pm 1.00(1.298)$ \\
\hline & 0.5 & $21.66 \pm 2.66(1.065)$ & $120.66 \pm 2.33(1.160)$ \\
\hline & 0.005 & $14.33 \pm 0.33(0.704)$ & $133.00 \pm 2.00(1.278)$ \\
\hline \multirow[t]{3}{*}{ P. pinnata } & 5 & $19.00 \pm 0.00(0.934)$ & $142.33 \pm 2.33(1.368)$ \\
\hline & 0.5 & $14.33 \pm 0.33(0.704)$ & $139.33 \pm 2.33(1.339)$ \\
\hline & 0.005 & $7.33 \pm 0.33(0.360)$ & $116.00 \pm 0.00$ \\
\hline 4 NQO & & $128.00 \pm 0.66(2 \mu \mathrm{g} / \mathrm{mL})$ & $389.33 \pm 1.33(1 \mu \mathrm{g} / \mathrm{mL})$ \\
\hline $10 \%$ DMSO & & $22.00 \pm 0.57(1.082)$ & $98.12 \pm 0.33(0.919)$ \\
\hline Water & & $20.33 \pm 0.88(1)$ & $101.00 \pm 3.00$ \\
\hline
\end{tabular}

gene mutations [31]. In all cases, the values fall within normal limits and in accordance with the literature [44].

\section{Conclusions}

D. multiflora and $P$. pinnata extracts had 15-LOX inhibitory effects. The LC-MS led to the identification of compounds with known biological activities in both extracts. No cytotoxic effect was observed with D. multiflora and $P$. pinnata on the tested cell lines. However, $P$. pinnata is devoid of useful antibacterial activity justifying the worse selectivity indices. Our study indicated the potential nongenotoxic effect of both plant samples tested. However, study including a metabolic activation step is necessary to approve this finding. The information on 15-LOX inhibitory effects, cytotoxicity, and genotoxicity of these plant samples motivates further research that aims at isolating and determining biological properties of safe compounds from both plants.

\section{Data Availability}

The data used to support the findings of this study are available from the corresponding author upon request.

\section{Conflicts of Interest}

The authors declare that they have no conflicts of interest.

\section{Authors' Contributions}

AAD conducted the practical work and prepared the draft of the manuscript, SVD performed LC-MS analysis, and MAN and EFX designed the study. All authors read and approved the final manuscript.

\section{Acknowledgments}

The authors are thankful to the African-German Network of Excellence in Science (AGNES), the German Federal Ministry of Education and Research (BMBF), and the Alexander von Humboldt Foundation $(\mathrm{AvH})$ through the programme AGNES Mobility Grant (Intra-Africa) for Junior Researchers for financial support. The authors are very grateful to Prof. Jacobus Nicolaas Eloff, Prof. Lyndy McGaw, and the Phytomedicine Programme, University of Pretoria, South Africa, for providing facilities for this study. They also thank the laboratory of Chemistry, Higher Teachers' Training College, University of Yaounde I, Cameroon for assistance in LC-MS analysis.

\section{References}

[1] E. Ricciotti and G. A. FitzGerald, "Prostaglandins and inflammation," Arteriosclerosis, Thrombosis, and Vascular Biology, vol. 31, no. 5, pp. 986-1000, 2011.

[2] A. S. Ravipati, L. Zhang, S. R. Koyyalamudi et al., "Antioxidant and anti-inflammatory activities of selected Chinese medicinal 
plants and their relation with antioxidant content," BMC Complementary and Alternative Medicine, vol. 12, no. 1, p. 173, 2012.

[3] J. Dzoyem, A. Donfack, P. Tane, L. McGaw, and J. Eloff, "Inhibition of nitric oxide production in LPS-stimulated RAW 264.7 macrophages and 15-LOX activity by Anthraquinones from Pentas Schimperi," Planta Medica, vol. 82, no. 14, pp. 1246-1251, 2016.

[4] V. Kuete, F. W. Fokou, O. Karaosmanoğlu, V. P. Beng, and H. Sivas, "Cytotoxicity of the methanol extracts of Elephantopus mollis, Kalanchoe crenata and 4 other Cameroonian medicinal plants towards human carcinoma cells," BMC Complementary and Alternative Medicine, vol. 17, no. 1, p. 280, 2017.

[5] F. Chaabane, J. Boubaker, A. Loussaif et al., "Antioxidant, genotoxic and antigenotoxic activities of Daphne gnidium leaf extracts," BMC Complementary and Alternative Medicine, vol. 12, no. 1, p. 153, 2012.

[6] A. Shafaei, K. Esmailli, E. Farsi, A. F. Aisha, A. M. Majid, and Z. Ismail, "Genotoxicity, acute and subchronic toxicity studies of nano liposomes of Orthosiphon stamineus ethanolic extract in Sprague Dawley rats," BMC Complementary and Alternative Medicine, vol. 15, no. 1, p. 360, 2015.

[7] A. Popat, N. H. Shear, I. Malkiewicz et al., "The toxicity of Callilepis laureola, a South African traditional herbal medicine," Clinical Biochemistry, vol. 34, no. 3, pp. 229-236, 2001.

[8] C. M. Mattana, M. A. Cangiano, L. E. Alcaráz et al., "Evaluation of cytotoxicity and genotoxicity of Acacia aroma leaf extracts," The Scientific World Journal, vol. 2014, Article ID 380850, 6 pages, 2014.

[9] A. Okem, J. F. Finnie, and J. Van Staden, "Pharmacological, genotoxic and phytochemical properties of selected South African medicinal plants used in treating stomach-related ailments," Journal of Ethnopharmacology, vol. 139, no. 3, pp. 712-720, 2012.

[10] A. D. Afagnigni, M. A. Nyegue, F. C. Ndoye, O. S. Voundi, M. C. Fonkoua, and F. X. Etoa, "Antibacterial and antioxidant activities of ethanolic leaves extracts of Dissotis multiflora Triana (Melastomataceae)," International Journal of Pharmaceutical Sciences and Drug Research, vol. 8, no. 1, pp. 50-56, 2016.

[11] A. D. Afagnigni, M. A. Nyegue, F. C. Ndoye et al., "Antidiarrheal activity of Dissotis multiflora (Sm) Triana (Melastomataceae) leaf extract in Wistar rats and sub-acute toxicity evaluation," Evidence-Based Complement Altern Med, vol. 2017, Article ID 4038371, 9 pages, 2017.

[12] K. Annan, P. J. Houghton, and R. Govindarajan, "In vitro and in vivo wound healing actions of Paullinia pinnata," Planta Medica, vol. 73, no. 9, p. 969, 2007.

[13] F. O. Jimoh, M. O. Sofidiya, and A. J. Afolayan, “Antioxidant properties of the methanol extracts from the leaves of Paullinia pinnata," Journal of Medicinal Food, vol. 10, no. 4, pp. 707-711, 2007.

[14] K. Annan, S. Y. Gbedema, and F. Adu, "Antibacterial and radical scavenging activity of fatty acids from Paullinia pinnata Linn," Pharmacognosy Magazine, vol. 4, pp. 119-123, 2009.

[15] L. D. Ior, M. O. Uguru, P. N. Olotu, T. L. Ohemu, and A. A. Ukpe, "Evaluation of analgesic and anti-inflammatory activities and phytochemical screening of the leaves extract of Paullinia pinnata (Sapindaceae)," Journal of Chemical and Pharmaceutical Research, vol. 3, no. 4, pp. 351-356, 2011.

[16] A. A. Lasisi, B. W. Ayinde, A. O. Adeleye, P. A. Onocha, I. A. Oladosu, and P. A. Idowu, "New triterpene isovanniloyl and antibacterial activity of constituents from the roots of
Paullinia pinnata Linn (Sapindaceae)," Journal of Saudi Chemical Society, vol. 19, no. 2, pp. 117-122, 2015.

[17] M. Aliyu, J. A. Anuka, A. H. Yaro, and M. G. Magaji, "Evaluation of the anxiolytic effect of methanolic leaves extract of Paullinia pinnata lin in mice," British Journal of Pharmaceutical Research, vol. 4, no. 13, pp. 1638-1646, 2014.

[18] P. Lunga, J. D. Tamokou, S. P. Fodouop, J.-R. Kuiate, J. Tchoumboue, and D. Gatsing, "Antityphoid and radical scavenging properties of the methanol extracts and compounds from the aerial part of Paullinia pinnata," SpringerPlus, vol. 3, no. 1, p. 302, 2014.

[19] A. D. Afagnigni, M. A. Nyegue, F. C. Ndoye, O. S. Voundi, M. C. Fonkoua, and F. X. Etoa, "In vitro assessment of antibacterial and antioxidant activities of ethanolic leaves extracts of Paullinia pinnata Linn (Sapindaceae)," World Journal of Pharmaceutical Sciences, vol. 4, no. 5, pp. 173-182, 2016b.

[20] K. Annan and P. J. Houghton, "Antibacterial activity of Paullinia pinnata extracts," in Proceedings of the Abstract of the Ninth International Congress, International Society of Ethnobiology, Canterbury, UK, 2004.

[21] R. S. Miemanang, K. Krohn, H. Hussain, and E. Dongo, "Paullinoside A and paullinomide A: a new cerebroside and a new ceramide from leaves of Paullinia pinnata," Zeitschrift für Naturforschung B, vol. 61, no. 9, pp. 1123-1127, 2006.

[22] E. Dongo, H. Hussain, R. S. Miemanang, D. Tazoo, B. Schulz, and K. Krohn, "Chemical constituents of Klainedoxa gabonenses and Paullinia pinnata," Records of Natural Products, vol. 3, no. 3, pp. 165-169, 2009.

[23] A. Z. Yusuf, A. Zakir, Z. Shemau, M. Abdullahi, and S. A. Halima, "Phytochemical analysis of the methanol leaves extract of Paullinia pinnata linn," Journal of Pharmacognosy and Phytotherapy, vol. 6, no. 2, pp. 10-16, 2014.

[24] D. Gatsing, P. K. Lunga, J. M. M. Nkodo, J. D. Tamokou, J. R. Kuiate, and J. Tchoumboue, "Post-treatment evaluation of the side effects of methanol leaf extract from Paullinia pinnata Linn, an antityphoid plant," Pharmacologia, vol. 6, no. 7, pp. 264-272, 2015.

[25] G. Abay, M. Altun, S. Koldaş, A. Tüfekçi, and I. Demirtas, "Determination of antiproliferative activities of volatile contents and HPLC profiles of dicranum scoparium (dicranaceae, bryophyta)," Combinatorial Chemistry \& High Throughput Screening, vol. 18, no. 5, pp. 453-463, 2015.

[26] A. Gheorghe, A. Van Nuijs, B. Pecceu et al., "Analysis of cocaine and its principal metabolites in waste and surface water using solid-phase extraction and liquid chromatography-ion trap tandem mass spectrometry," Analytical and Bioanalytical Chemistry, vol. 391, no. 4, pp. 1309-1319, 2008.

[27] M. Pinto, A. Tejeda, A. L. Duque, and P. Macías, "Determination of lipoxygenase activity in plant extracts using a modified ferrous oxidation-xylenol orange assay," Journal of Agricultural and Food Chemistry, vol. 55, no. 15, pp. 59565959, 2007.

[28] K. E. Motlhatlego, E. Mfotie Njoya, M. A. Abdalla, J. N. Eloff, and L. J. McGaw, "The potential use of leaf extracts of two Newtonia (Fabaceae) species to treat diarrhoea," South African Journal of Botany, vol. 116, pp. 25-33, 2018.

[29] T. Mosmann, "Rapid calorimetric assay for cellular growth and survival: application to proliferation and cytotoxic assays," Journal of Immunological Methods, vol. 65, no. 1-2, pp. 263-271, 1983.

[30] G. T. Omokhua, M. A. Abdalla, J. Van Staden, and L. J. McGaw, "A comprehensive study of the potential phytomedicinal use and toxicity of invasive Tithonia species in 
South Africa," BMC Complementary and Alternative Medicine, vol. 18, p. 272, 2018.

[31] D. M. Maron and B. N. Ames, "Revised methods for the Salmonella mutagenicity test," Mutation Research/Environmental Mutagenesis and Related Subjects, vol. 113, no. 3-4, pp. 173-215, 1983.

[32] J. Němeček, P. Sychra, M. Macháček et al., "Structure-activity relationship studies on 3,5-dinitrophenyl tetrazoles as antitubercular agents," European Journal of Medicinal Chemistry, vol. 130, pp. 419-432, 2017.

[33] T. Akihisa, Y. Nishimoto, E. Ogihara, M. Matsumoto, J. Zhang, and M. Abe, "Nitric oxide production-inhibitory activity of limonoids from Azadirachta indica and Melia azedarach," Chemistry \& Biodiversity, vol. 14, no. 6, Article ID e1600468, 2017.

[34] M. Cho, G.-M. Park, S.-N. Kim, T. Amna, S. Lee, and W.-S. Shin, "Glioblastoma-specific anticancer activity of pheophorbide a from the edible red seaweed Grateloupia elliptica," Journal of Microbiology and Biotechnology, vol. 24, no. 3, pp. 346-353, 2014.

[35] P. M.-K. Tang, J. Y.-W. Chan, S. W.-N. Au et al., "Pheophorbide a, an active compound isolated fromScutellaria barbata, possesses photodynamic activities by inducing apoptosis in human hepatocellular carcinoma," Cancer Biology \& Therapy, vol. 5, no. 9, pp. 1111-1116, 2006.

[36] I. Schneider and F. Bucar, "Lipoxygenase inhibitors from natural plant sources: part 1 -medicinal plants with inhibitory activity on arachidonate 5-lipoxygenase and 5 lipoxygenase/cycloxygenase," Phytotherapy Research, vol. 19, no. 2, pp. 81-102, 2005.

[37] H. Wangensteen, A. B. Samuelsen, and K. E. Malterud, "Antioxidant activity in extracts from coriander," Food Chemistry, vol. 88, no. 2, pp. 293-297, 2004.

[38] G. N. Zirihi, L. Mambu, F. Guédé-Guina, B. Bodo, and P. Grellier, "In vitro antiplasmodial activity and cytotoxicity of 33 West African plants used for treatment of malaria," Journal of Ethnopharmacology, vol. 98, no. 3, pp. 281-285, 2005.

[39] N. I. Mongalo, L. J. McGaw, J. F. Finnie, and J. Van Staden, "Pharmacological properties of extracts from six South African medicinal plants used to treat sexually transmitted infections (STIs) and related infections," South African Journal of Botany, vol. 112, pp. 290-295, 2017.

[40] J. M. Nguta, R. Appiah-Opong, A. K. Nyarko et al., "Antimycobacterial and cytotoxic activity of selected medicinal plant extracts," Journal of Ethnopharmacology, vol. 182, pp. 10-15, 2016.

[41] T. A. Abere, P. E. Okoto, and F. O. Agoreyo, “Antidiarrheal and toxicological evaluation of the leaf extract of Dissotis rotundifolia Triana (Melastomataceae)," BMC Complementary and Alternative Medicine, vol. 10, p. 71, 2010.

[42] S. O. Adeyemo and J. M. Makinde, "Acute and sub-acute toxicity studies of the methanol extract of the leaves of Paullinia pinnata Linn in Wistar mice and rats," African Journal of Medicine and Medical Sciences, vol. 42, no. 1, pp. 81-90, 2013.

[43] V. Kuete, "Potential of Cameroonian plants and derived products against microbial infections: a review," Planta Medica, vol. 76, no. 14, pp. 1479-1491, 2010.

[44] E. Elgorashi, J. L. Taylor, A. Maes, J. Van staden, N. De kimpe, and L. Verschaeve, "Screening of medicinal plants used in South African traditional medicine for genotoxic effects," Toxicology Letters, vol. 143, no. 2, pp. 195-207, 2003. 